\title{
Occurrence and Distribution of a Diatom-Diazotrophic Cyanobacteria Association during a Trichodesmium Bloom in the Southeastern Arabian Sea
}

\author{
T. Jabir, ${ }^{1}$ V. Dhanya, ${ }^{2}$ Y. Jesmi, ${ }^{1}$ M. P. Prabhakaran, ${ }^{1}$ N. Saravanane, ${ }^{2}$ \\ G. V. M. Gupta, ${ }^{2}$ and A. A. M. Hatha ${ }^{1}$ \\ ${ }^{1}$ Department of Marine Biology, Microbiology and Biochemistry, School of Marine Sciences, \\ Cochin University of Science and Technology, Fine Arts Avenue, Kochi 682016, Kerala, India \\ ${ }^{2}$ Centre for Marine Living Resources and Ecology, Kendriya Bhavan, Kakkanad, CSEZ P.O., Kochi 682037, Kerala, India
}

Correspondence should be addressed to A. A. M. Hatha; mohamedhatha@gmail.com

Received 4 May 2013; Accepted 12 July 2013

Academic Editor: Renzo Perissinotto

Copyright (C) 2013 T. Jabir et al. This is an open access article distributed under the Creative Commons Attribution License, which permits unrestricted use, distribution, and reproduction in any medium, provided the original work is properly cited.

Symbiotic diatom-diazotrophic cyanobacteria association (DDA) of Rhizosolenia hebetata and Rhizosolenia formosa with endosymbiotic cyanobacteria Richelia intracellularis was noticed and documented for the first time during a bloom of the cyanobacterium Trichodesmium erythraeum in the oligotrophic shelf waters along Kochi and Mangalore transects, southeastern Arabian Sea (SEAS), during spring intermonsoon (April 2012). Although the host is frequently seen, the symbiont is rarely reported in the Indian EEZ. The presence of nitrogen-fixing symbiotic association of Rhizosolenia-Richelia along with Trichodesmium erythraeum highlights the significance of DDAs on the nutrient and energy budgets of phytoplankton in the oligotrophic environments of the Arabian Sea during spring intermonsoon.

\section{Introduction}

Planktonic organisms that fix atmospheric nitrogen (diazotrophs) have a critical role in oceanic production and in the marine nitrogen cycle [1]. Abundance and growth rates of such organisms depend on their ability to assimilate various sources of nitrogen [2]. The availability of fixed nitrogen (such as nitrate and ammonium) can limit the productivity of the sea [3]. Diatom-diazotroph associations (DDAs) are widely reported in oligotrophic waters and have the capacity to form episodic, largely monospecific blooms that exhibit very high rates of carbon and nitrogen fixation worldwide [4-7]. Annually, Trichodesmium contributes 1$5 \mathrm{mmol} \mathrm{N} \mathrm{m} \mathrm{d}^{-1}$; while diazotrophic diatoms, contribute $0.4-2.4 \mathrm{mmol} \mathrm{N} \mathrm{m}^{-2} \mathrm{~d}^{-1}$, which forms one quarter of the total input of nitrogen to the sea [8]. Globally, DDAs fix $4.79 \mathrm{Tg} \mathrm{Ny}^{-1}$ [9], which forms almost $25 \%$ of total input of nitrogen to the sea [8].

One of the most conspicuous free-living, diazotrophic species is the colony-forming cyanobacteria, a species of the Trichodesmium that is found throughout tropical and subtropical oceans and forms large-scale surface blooms [10]. A unique group of open ocean diazotrophs is the heterocystous cyanobacteria that live symbiotically with other members of phytoplankton, primarily diatoms. Such endosymbiotic associations help most of the diatoms to fix atmospheric nitrogen in oligotrophic waters with the help of such endosymbiotic associations [11-13]. The cyanobacteria, Richelia intracellularis and Calothrix rhizosoleniae, were found in association with diatom genera such as Rhizosolenia, Hemiaulus, Bacteriastrum, and Chaetoceros. They are also seen as epiphyte or endosymbiont in Guinardia cylindrus in warm tropical and subtropical oligotrophic waters [6, 12 , 14]. Only a few workers have reported RhizosoleniaRichelia associations from the Indian Exclusive Economic Zone (EEZ) [15-18]. Several reports [15-17] described the occurrence of this species from the southeast coast of India, while there is only one report [18] from the northeastern Arabian Sea (NEAS). There are no reports on this aspect from the southeastern Arabian Sea (SEAS). This report forms the first in this regard. 


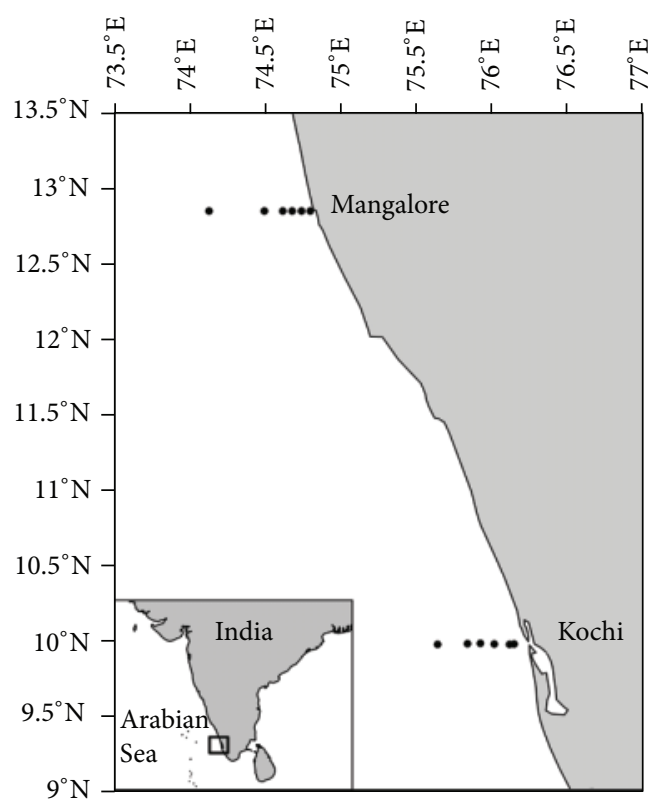

FIGURE 1: Study area showing sampling locations.

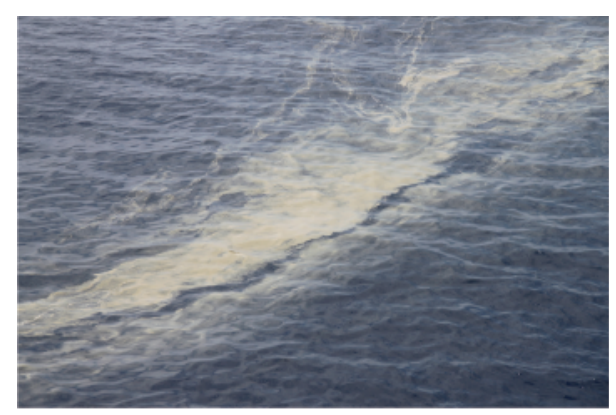

FIGURE 2: Trichodesmium erythraeum bloom observed in the coastal waters along Kochi transect during April 2012.

\section{Materials and Methods}

The study was a part of monthly observations made in the southeastern Arabian Sea (SEAS), and observations made along the Kochi and Mangalore transects during April 2012 (spring intermonsoon) are reported in this paper (Figure 1). Surface water samples were collected from both of these transects onboard Fisheries and Oceanographic Research Vessel (FORV) Sagar Sampada. Surface samples were collected from six stations based on depth $(13,20,30,40,50$, and $100 \mathrm{~m}$ ). A surface sample was also collected from a bloom of Trichodesmium erythraeum located between the 50 and $100 \mathrm{~m}$ stations along Kochi transect $\left(9^{\circ} 57^{\prime} 52^{\prime \prime} \mathrm{N} ; 75^{\circ} 50^{\prime} 38^{\prime \prime} \mathrm{E}\right.$, Figure 2).

Temperature and salinity data were obtained using a CTD rosette system (Sea-Bird SBE 911 plus). Dissolved oxygen (Winkler's method) and nutrients in the sea water were determined using standard procedures [19]. Surface sea water samples were collected using a bucket sampling method. Twenty-five liters of sample were filtered through $20 \mu \mathrm{m}$ bolting silk net and preserved in 3\% formalin and Lugol's
TABLE 1: Hydrographical variables observed along the Kochi and Mangalore transects during April 2012.

\begin{tabular}{lcc}
\hline \multirow{2}{*}{ Variables } & \multicolumn{2}{c}{ Range of observed values } \\
& Kochi & Mangalore \\
\hline Temperature $\left({ }^{\circ} \mathrm{C}\right)$ & $30.10-30.70$ & $30.06-31.44$ \\
Salinity $(\mathrm{psu})$ & $33.89-35.01$ & $34.60-35.19$ \\
Wind speed $\left(\mathrm{ms}^{-1}\right)$ & $2.41-13.98$ & $2.44-9.97$ \\
DO $\left(\mathrm{mlL}^{-1}\right)$ & $4.02-4.94$ & $4.05-4.69$ \\
Ammonia $(\mu \mathrm{M})$ & $0.41-1.94$ & $0.37-1.69$ \\
Nitrate $(\mu \mathrm{M})$ & $0.06-1.96$ & $0.04-0.24$ \\
Silicate $(\mu \mathrm{M})$ & $0.49-1.58$ & $1.70-5.30$ \\
Phosphate $(\mu \mathrm{M})$ & $0.11-0.52$ & $0.03-0.56$ \\
\hline
\end{tabular}

iodine. Live and preserved samples were analysed using a Nikon Eclipse microscope with a Nikon DN 100 series digital camera, and photomicrographs of the samples were taken. Identification of species was done using standard references $[20,21]$

\section{Results and Discussion}

The endophytic cyanobacteria were identified as Richelia intracellularis J. Schmidt 1901. The systematic position of $R$. intracellularis is given below:

$$
\begin{aligned}
& \text { class: Cyanophyceae, } \\
& \text { order: Nostocales, } \\
& \text { family: Nostocaceae, } \\
& \text { subfamily: Anabaenoideae. }
\end{aligned}
$$

Trichomes of Richelia intracellularis are solitary, short, 1320 celled, straight or slightly arcuated, more or less cylindrical along the whole length, without sheaths or gelatinous envelopes, isopolar, and slightly constricted at cross-walls. Heterocytes are more or less spherical and develop terminally on one or (later) on both ends; they are spherical, wider than vegetative cells. Akinetes are lacking. They are marine in nature and generally seen as endophytic within cells (intracellular) of oceanic planktonic diatoms, mainly in species of Rhizosolenia and sometimes in species of Hemiaulus and as epiphytic on species of Chaetoceros $[6,12$, $14]$. However, in the present study, $R$. intracellularis was found to be symbiotic in Rhizosolenia hebetata and R. formosa. The occurrence of this diatom-diazotroph association is the first record from the coastal waters of SEAS. Examination of slide preparations of the collected samples using epifluorescence microscopy revealed the presence of RhizosoleniaRichelia symbioses. Two trichomes of $R$. intracellularis having unequal length were observed within the cells of Rhizosolenia hebetata (Figure 3(a)) and four trichomes within R. formosa (Figure 3(b)). The prevailing hydrographic conditions are given in Table 1, which depicts the tropical and oligotrophic characteristics of these coastal waters.

Examination of preserved samples using bright field inverted microscopy revealed the presence of RhizosoleniaRichelia symbiosis. Cells of Rhizosolenia hebetata containing 


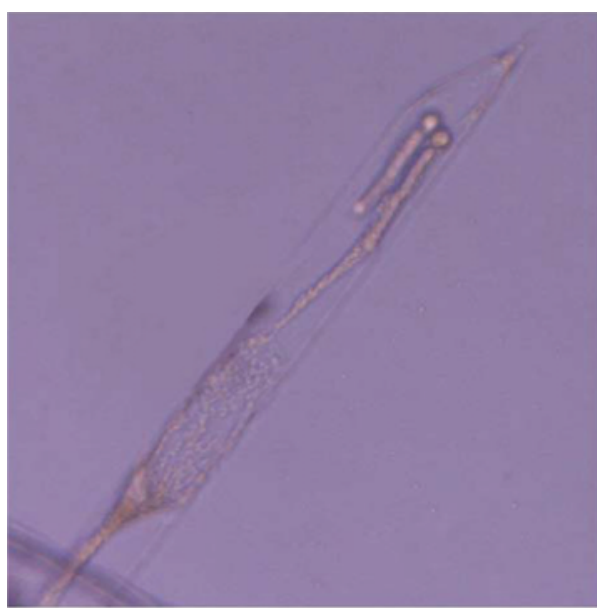

(a)

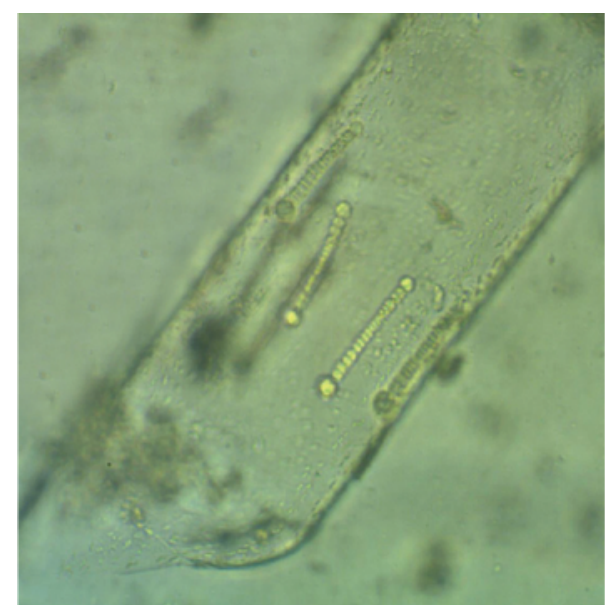

(b)

Figure 3: (a) Rhizosolenia hebetata with trichomes of Richelia intracellularis $(\times 400)$. (b) Rhizosolenia formosa $(\times 400)$ with trichomes of Richelia intracellularis.

Richelia intracellularis, in general, had two trichomes with heterocyst located at the ends of the filaments (Figure 3(a)). Free living trichomes were not observed during the entire study. Rhizosolenia hebetata was the only host diatom observed from the Kochi transect. It was also the dominant host along the Mangalore transect, except at station 2 where Rhizosolenia formosa was dominant with four trichomes in each diatom cell (Figure 3(b)). Although Rhizosolenia hebetata was found at all the stations, the DDAs were seen only at deeper stations (40-100 m) along the Kochi transect (Figure 4(a)) and beyond $20 \mathrm{~m}$ along the Mangalore transect (Figure 4(b)).

Distribution of major groups in the phytoplankton showed that diatoms were dominant along both the Kochi and Mangalore transects, constituting $83 \%$ and 58\%, respectively, of the total phytoplankton population (Figures 5(a) and 5(b)), followed by cyanobacteria and dinoflagellates. Trichodesmium erythraeum constituted $45-85 \%$ and $40-60 \%$ of the total cyanobacteria from the Kochi and Mangalore transects respectively. Rhizosolenia constituted $0.4 \%$ and $0.6 \%$ of the total diatoms at the two transects, respectively. Numerical abundance of cells containing diazotrophs was less than 5 cells $\mathrm{L}^{-1}$ at both of the transects. The occurrence was more widespread along the Mangalore transect where it was observed at all stations except at $13 \mathrm{~m}$ depth station. The bloom sample taken from deeper stations along the Kochi transect farther waters was dominated by Trichodesmium erythraeum (over $85 \%$ ), while diatoms constituted only $6.4 \%$. Rhizosolenia hebetata with endosymbiotic Richelia intracellularis abundance in the bloom sample was found to be 6 cells $\mathrm{L}^{-1}$.

The blooming of the cyanobacterium Trichodesmium erythraeum is commonly seen in the SEAS during peak SIM (April-May) when favourable conditions like very warm, calm, and nitrogen depleted conditions prevail [18]. During the present observation period, there were near nitrate depleted conditions at most of the stations (Table 1), which is sufficient enough for Trichodesmium erythraeum to proliferate and bloom. Interestingly, the Rhizosolenia-Richelia association was seen only with Trichodesmium erythraeum, which means that the environmental requirements for these to occur are the same. The diazotrophs release fixed nitrogen as ammonium or dissolved organic nitrogen, which is then available to the nutrient starved nondiazotrophic community [8]. Nitrate and phosphate concentrations were comparatively low in the study area (Table 1).

Richelia intracellularis has been reported to be among the most important and widespread nitrogen-fixing, endosymbiotic cyanobacteria in marine pelagic tropical and subtropical waters [22, 23]. However, reports of such studies in the Arabian Sea are scant and not previously documented from the SEAS. The heterocystous $R$. intracellularis is an extracellular endosymbiont, which locates itself in the periplasmic space between the plasmalemma and silica cell wall in the diatoms [22]. It was found as an endosymbiont in five species of Rhizosolenia, Hemiaulus membranaceus, H. hauckii, and Guinardia cylindrus and rarely as an epiphyte on Chaetoceros species, or exists freely in water [22]. It is assumed that the abundance of endosymbiotic cyanobacteria was due to their capacity to fix atmospheric nitrogen in oligotrophic waters.

This is the first reported observation on the occurrence of the nitrogen-fixing, endosymbiotic cyanobacterium, Richelia intracellularis in Rhizosolenia hebetata and R. formosa in the SEAS along with Trichodesmium erythraeum blooms, which occurred off most parts of Kochi and Mangalore transects and appeared like a saw-dust mat in the surface waters (Figure 2). These waters were characterised by stratification during the spring intermonsoon (SIM) and strong upwelling during the summer monsoon [24]. The Arabian Sea during the SIM (March-May) is renowned for its stratified condition, which results in nutrient poor oligotrophic surface waters (Table 1). Such conditions favour high abundance of nitrogen-fixing 


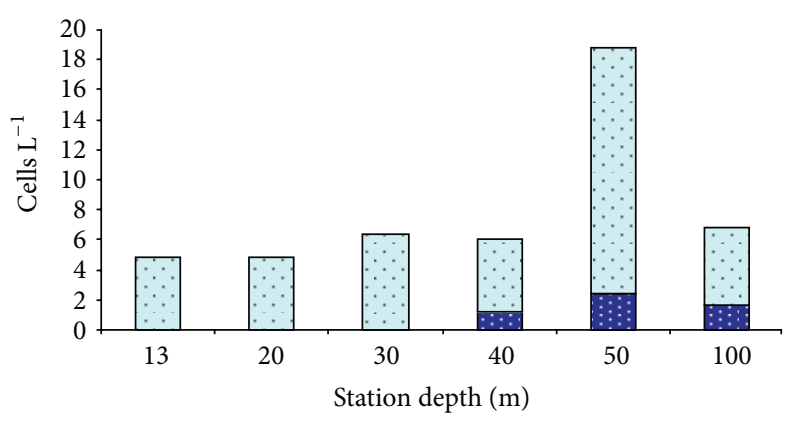

$\square$ Rhizosolenia without Richelia Rhizosolenia with Richelia

(a)

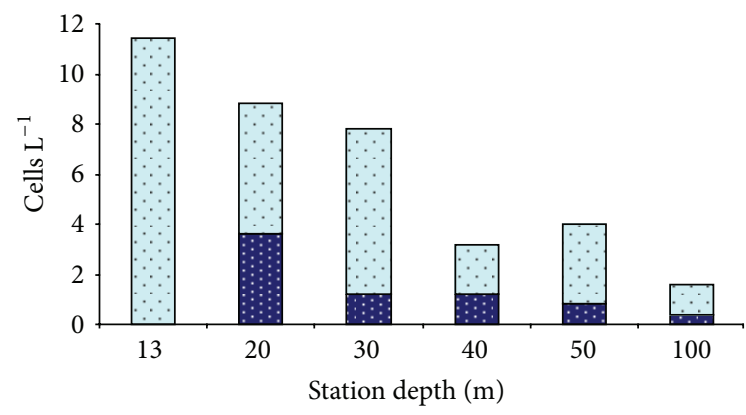

$\square$ Rhizosolenia without Richelia

- Rhizosolenia with Richelia

(b)

FIgure 4: Cell density of Rhizosolenia with and without Richelia intracellularis along (a) Kochi and (b) Mangalore transects.

cyanobacteria in both coastal and open ocean waters. It was observed that the occurrence of Rhizosolenia species with Richelia intracellularis was coincided with Trichodesmium erythraeum where nitrate levels were very low $(0.04-1.96 \mu \mathrm{M})$ and ammonium concentrations were sufficiently high (0.37$1.94 \mu \mathrm{M})$. This indicates that the diazotrophs along with cyanophyceans not only support the production of a nondiazotrophic phytoplankton community through regenerated ammonium produced from these nitrogen fixers [17], but also play a significant role in nitrogen cycling and the budget of oligotrophic SEAS during the SIM.

Observations on diatom-diazotroph symbioses are lacking in the eastern Arabian Sea as the importance of DDAs in the nutrient budget of these oligotrophic waters is unknown. The nutrient profile of the study area reflects the oligotrophic conditions, which may have resulted in the RhizosoleniaRichelia symbiosis. Forming a symbiotic association might then be considered as an ecological adaptation to life in the oligotrophic ocean. Compared to their terrestrial counterparts [25], marine symbiotic systems are greatly understudied, and thus many intricacies of these relationships remain largely unresolved. This paper reports the first observation of occurrence of DDAs and is evidence for the presence of symbiotic association of nitrogen-fixing organisms in SEAS. This study is based on the visual examination of

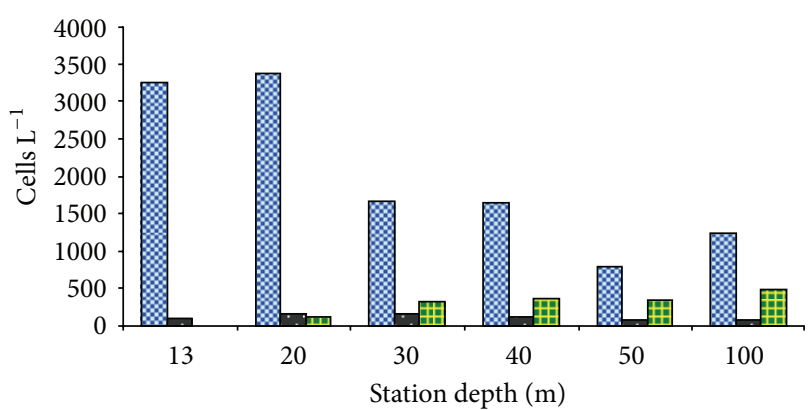

Diatom

- Dinoflagellate

$\rightarrow$ Cyanobacteria

(a)

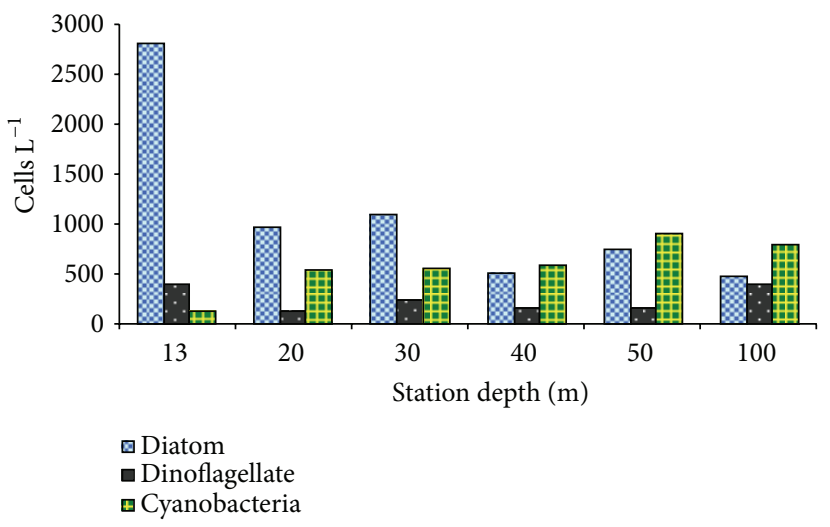

(b)

FIGURE 5: Distribution of major groups in the phytoplankton along (a) Kochi and (b) Mangalore transects.

diatom assemblages using light microscopy. It highlights the presence of potentially significant DDAs in the highly productive SEAS, which directly affect the oceanic nutrient inventory through the addition of new nitrogen to the ocean ecosystem. Although there have been observations on blooms of Trichodesmium species in the Arabian Sea, there have been relatively few reports on the contribution of nitrogen fixation by cyanobacteria to the marine nitrogen budget [26]. According to Gandhi et al. [27], nitrogen fixation by Trichodesmium species occurs mainly in the upper $10 \mathrm{~m}$ of the ocean surface and their fluxes to the Arabian Sea were estimated to be at $15.4 \pm 1.5 \mathrm{Tg} \mathrm{Ny}^{-1}$ which is equivalent to $\sim 92 \%$ of total "new" nitrogen supply to the Arabian Sea and $\sim 11 \%$ of the global nitrogen fixation. DDAs, although found less in number in the SEAS during the present study, symbiotically support noncyanophyceans (diatoms) in fixing nitrogen for their metabolic activity; thereby their role in the nitrogen cycling of the region is very important.

\section{Conclusion}

The present study highlights the presence of diatomdiazotroph symbiotic associations, which, along with Trichodesmium erythraeum, influence the nutrient and energy 
budgets of phytoplankton in the oligotrophic environment of the SEAS.

\author{
Abbreviations \\ SEAS: Southeastern Arabian Sea \\ NEAS: Northeastern Arabian Sea \\ DDA: Diatom-diazotrophic association \\ SIM: Spring intermonsoon \\ EEZ: Exclusive Economic Zone.
}

\section{Acknowledgments}

This work was supported by the Ministry of Earth Sciences (MoES), Government of India, under the Sustained Indian Ocean Biogeochemical Cycle and Ecological Research (SIBER) programme. The authors are thankful to the Centre for Marine Living Resources and Ecology (CMLRE), Kochi, India, and the researchers and staff members of FORV Sagar Sampada for providing the facilities for sampling and also to the Head, Department of Marine Biology, Microbiology and Biochemistry, School of Marine Sciences, Cochin University of Science and Technology (CUSAT), Kochi, for providing necessary facilities for carrying out this work.

\section{References}

[1] J. E. Dore, R. M. Letelier, M. J. Church, R. Lukas, and D. M. Karl, "Summer phytoplankton blooms in the oligotrophic North Pacific Subtropical Gyre: historical perspective and recent observations," Progress in Oceanography, vol. 76, no. 1, pp. 2-38, 2008.

[2] B. D. Jenkins, J. P. Zehr, A. Gibson, and L. Campbell, "Cyanobacterial assimilatory nitrate reductase gene diversity in coastal and oligotrophic marine environments," Environmental Microbiology, vol. 8, no. 12, pp. 2083-2095, 2006.

[3] A. White, "The trouble with the bubble," Nature, vol. 488, pp. 290-291, 2012.

[4] R. A. Foster, A. Subramaniam, C. Mahaffey, E. J. Carpenter, D. G. Capone, and J. P. Zehr, "Influence of the Amazon River plume on distributions of free-living and symbiotic cyanobacteria in the western tropical north Atlantic Ocean," Limnology and Oceanography, vol. 52, no. 2, pp. 517-532, 2007.

[5] L. Martínez, M. W. Silver, J. M. King, and A. L. Alldredge, "Nitrogen fixation by floating diatom mats: a source of new nitrogen to oligotrophic ocean waters," Science, vol. 221, no. 4606, pp. 152-154, 1983.

[6] A. L. Alldredge and M. W. Silver, "Abundance and production rates of floating diatom mats (Rhizosolenia castracanei and $R$. imbricata var. shrubsolei) in the Eastern Pacific Ocean," Marine Biology, vol. 66, no. 1, pp. 83-88, 1982.

[7] T. H. Mague, N. M. Weare, and O. Holm-Hansen, "Nitrogen fixation in the North Pacific Ocean," Marine Biology, vol. 24, no. 2, pp. 109-119, 1974.

[8] A. J. Poulton, M. C. Stinchcombe, and G. D. Quartly, "High numbers of Trichodesmium and diazotrophic diatoms in the southwest Indian Ocean," Geophysical Research Letters, vol. 36, no. 15, Article ID L15610, 2009.
[9] E. J. Carpenter, J. P. Montoya, J. Burns, M. R. Mulholland, A. Subramaniam, and D. G. Capone, "Extensive bloom of a $\mathrm{N}_{2}$ fixing diatom/cyanobacterial association in the tropical Atlantic Ocean," Marine Ecology Progress Series, vol. 185, pp. 273-283, 1999.

[10] D. G. Capone, J. A. Burns, J. P. Montoya et al., "Nitrogen fixation by Trichodesmium spp.: an important source of new nitrogen to the tropical and subtropical North Atlantic Ocean," Global Biogeochemical Cycles, vol. 19, no. 2, Article ID GB2024, pp. 117, 2005.

[11] R. A. Foster, A. Subramaniam, and J. P. Zehr, "Distribution and activity of diazotrophs in the Eastern Equatorial Atlantic," Environmental Microbiology, vol. 11, no. 4, pp. 741-750, 2009.

[12] M. E. Ferrario, V. Villafane, W. Helbling, and O. Holm-Hansen, "The occurrence of the symbiont Richelia in Rhizosolenia and Hemiaulus in the North Pacific," Revista Brasileira de Biologia, vol. 55, no. 3, pp. 439-443, 1995.

[13] T. A. Villareal, "Marine nitrogen-fixing diatom-cyanobacteria symbioses," in Marine Pelagic Cyanobacteria: Trichodesmium and Other Diazotrophs, E. J. Carpenter, D. G. Capone, and J. G. Rueter, Eds., pp. 163-175, Kluwer Academic Publishers, Amsterdam, The Netherlands, 1992.

[14] F. Gómez, K. Furuya, and S. Takeda, "Distribution of the cyanobacterium Richelia intracellularis as an epiphyte of the diatom Chaetoceros compressus in the western Pacific Ocean," Journal of Plankton Research, vol. 27, no. 4, pp. 323-330, 2005.

[15] M. O. P. Iyengar and T. V. Desikachary, "A systematic account of some marine Myxophyceae of the South Indian coast," Journal of Madras University, vol. 16, pp. 37-63, 1944.

[16] R. Subrahmanyan, "A systematic account of the marine plankton diatoms of the Madras coast," Proceedings of the Indian Academy of Sciences B, vol. 24, no. 4, pp. 85-197, 1946.

[17] V. V. Kulkarni, R. R. Chitari, D. D. Narale, J. S. Patil, and A. C. Anil, "Occurrence of cyanobacteria-diatom symbiosis in the Bay of Bengal: implications in biogeochemistry," Current Science, vol. 99, no. 6, pp. 736-737, 2010.

[18] K. B. Padmakumar, B. R. Smitha, L. C. Thomas et al., "Blooms of Trichodesmium erythraeum in the South Eastern Arabian Sea during the onset of 2009 summer monsoon," Ocean Science Journal, vol. 45, no. 3, pp. 151-157, 2010.

[19] K. Grasshoff, M. Erhardt, and K. Kremling, Eds., Methods of Seawater Analysis, Chemie, Weinheim, Germany, 2nd edition, 1983.

[20] C. R. Tomas, Identifying Marine Phytoplankton, Academic press, New York, NY, USA, 1997.

[21] R. Santhanam, N. Ramanathan, K. Venkataramanujam, and G. Jegatheesan, "Phytoplankton of the Indian seas," in An Aspects of Marine Botany, Daya, Delhi, India, 1987.

[22] T. J. Lyimo, "Distribution and abundance of the cyanobacterium Richelia intracellularis in the coastal waters of Tanzania," Journal of Ecology and the Natural Environment, vol. 3, no. 3, pp. 85-94, 2011.

[23] S. Janson, J. Wouters, B. Bergman, and E. J. Carpenter, "Host specificity in the Richelia-diatom symbiosis revealed by hetR gene sequence analysis," Environmental microbiology, vol. 1, no. 5, pp. 431-438, 1999.

[24] H. Habeebrehman, M. P. Prabhakaran, J. Jacob et al., "Variability in biological responses influenced by upwelling events in the Eastern Arabian Sea," Journal of Marine Systems, vol. 74, no. 1-2, pp. 545-560, 2008. 
[25] A. N. Rai, E. Söderbäck, and B. Bergman, "Cyanobacteriumplant symbioses," New Phytologist, vol. 147, no. 3, pp. 449-481, 2000.

[26] T. K. Westberry and D. A. Siegel, "Spatial and temporal distribution of Trichodesmium blooms in the world's oceans," Global Biogeochemical Cycles, vol. 20, no. 4, Article ID GB4016, 2006.

[27] N. Gandhi, A. Singh, S. Prakash et al., "First direct measurements of $\mathrm{N}_{2}$ fixation during a Trichodesmium bloom in the eastern Arabian Sea," Global Biogeochemical Cycles, vol. 25, no. 4, Article ID GB4014, 2011. 

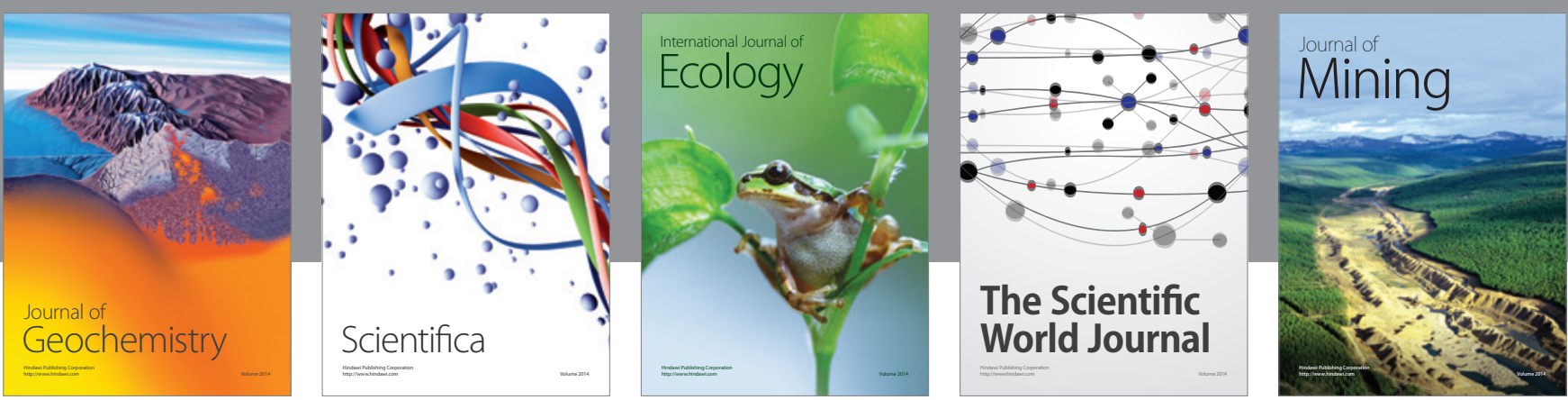

The Scientific World Journal
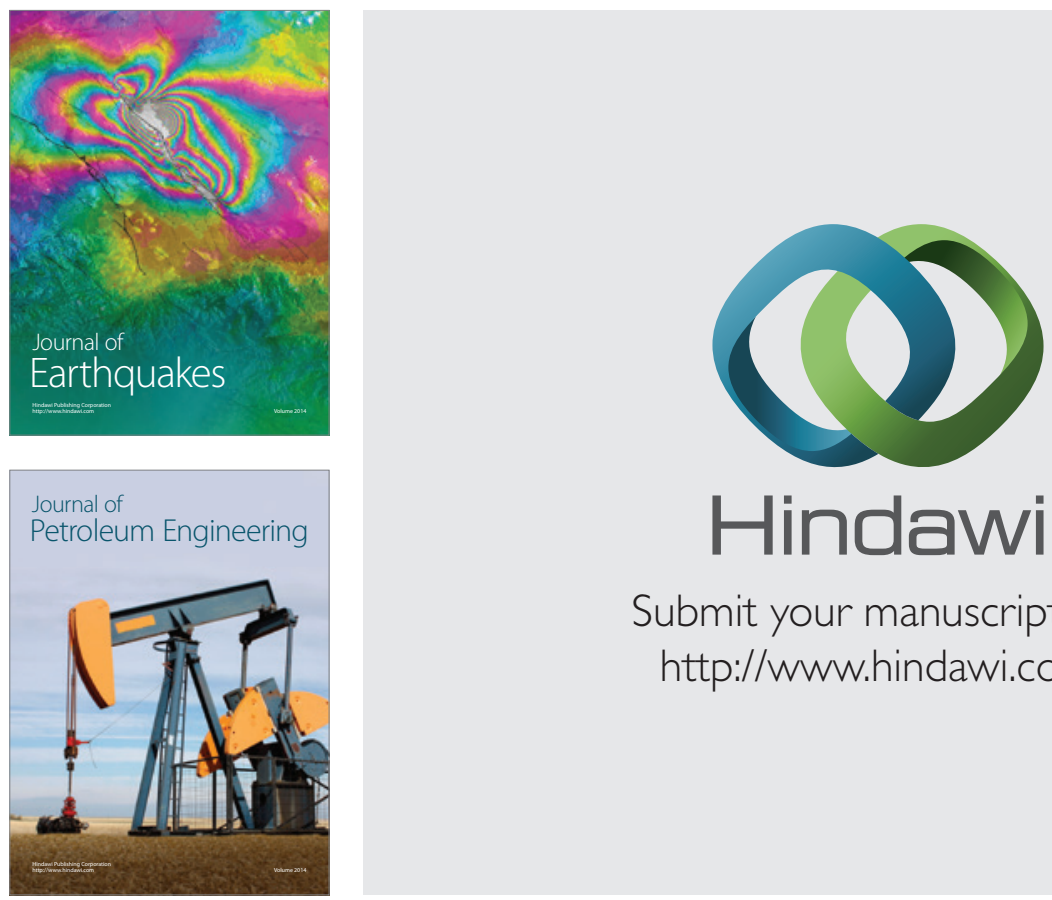

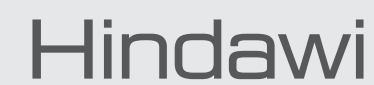

Submit your manuscripts at

http://www.hindawi.com
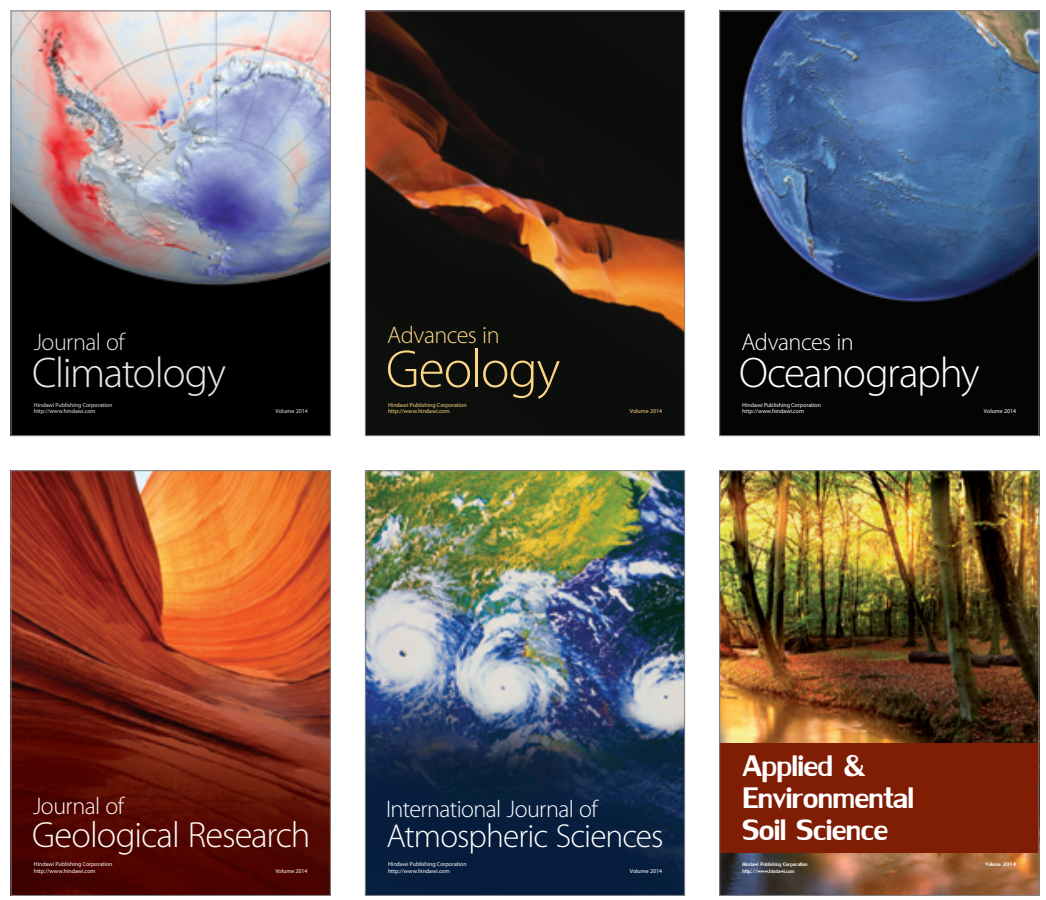
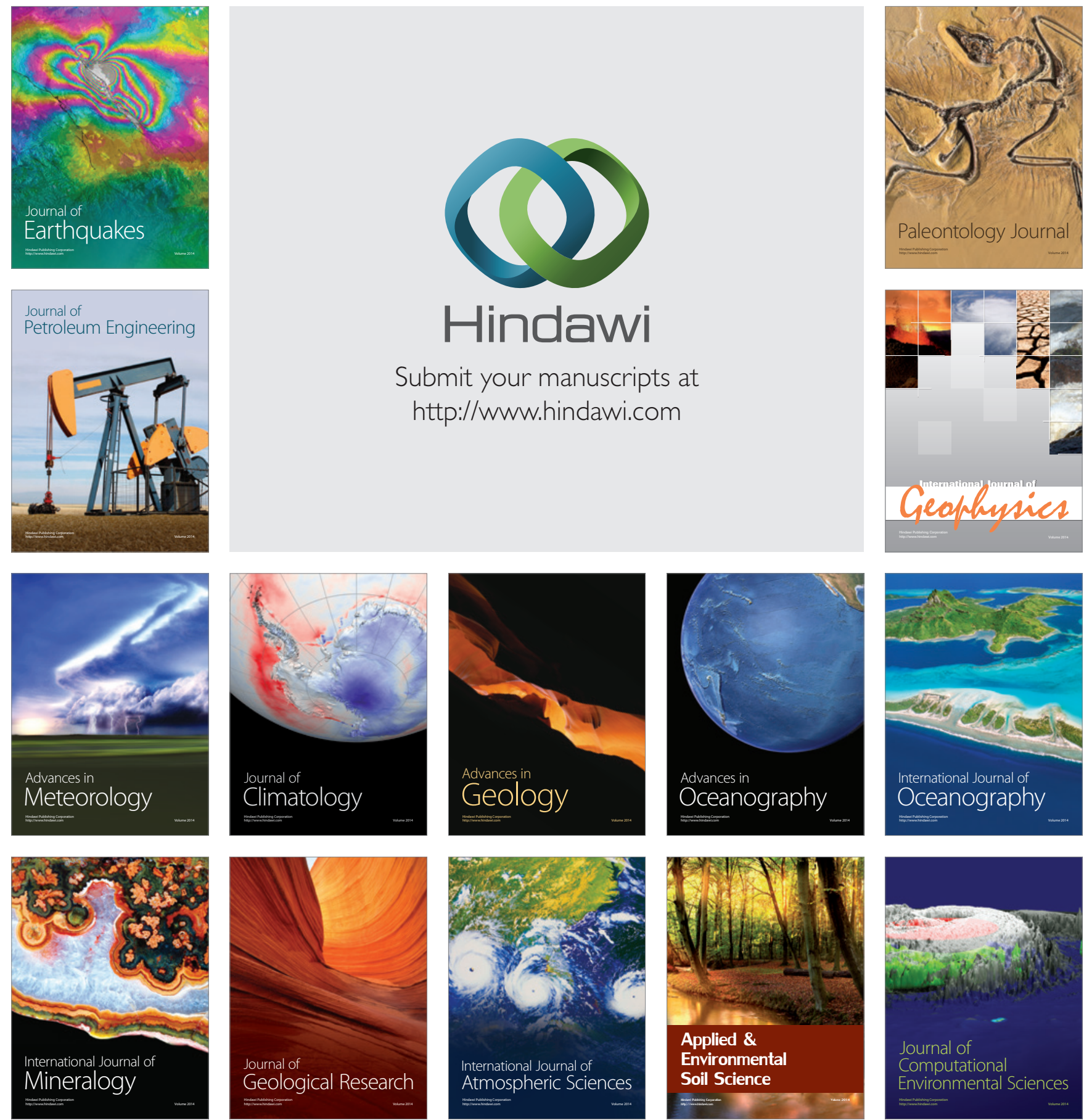